\title{
The Relation Between The Perception Of Marketing Mix And The Decision To Have Outpatient Treatment In RSIJ Pondok Kopi In 2018
}

\author{
Nindya Julianingsih, Mustakim \\ Universitas Muhammadiyah Jakarta, Indonesia \\ nindyajulianingsih@gmail.com
}

\begin{abstract}
Consumers play such an important role that without them a company's asset will have no worth. Therefore, it is important for a company to satisfy its costumers and attract their interest. One of the actions a company, or in this term a hospital, can do to advertise its products is to improve a good marketing. The purpose of this research is to know the relation between the perception of marketing mix and the dedision to have outpatient treatment in RSIJ Pondok Kopi in 2018. This research conducted from April to June 2018 is descriptive-analytic research using the cross sectional design. The research involved 120 outpatients as the research sample using the purposive sampling technique. The research found that as many as 65 respondents $((54.2 \%))$ decided to have an outpatient treatment. It also found that some aspects of marketing mix, which included products, price, place, promotion, human resources and process, were had a significant relation to the decision; meanwhile, the aspect of physical evident was found not to do so. Therefore, it is important that the hospital maintain and improve the quality of its delivered services through providing excellent, professional services and add bench seats on which patients sit waiting for prescribed drugs.
\end{abstract}

Key words: Marketing Mix, Decision to choose, and Perception 


\section{STRADA Jurnal Ilmiah Kesehatan}

DOI: $10.30994 /$ sjik.v9i1.210

ISSN: 2252-3847 (print); 2614-350X (online)

Vol.9 No.1. May 2020. Page.206-218

\section{INTRODUCTION}

Hospitals form a health-care service operated by public or private agencies (Aditama, 2004). In Indonesia, hospitals are facing changes of people's behavior and needs as well as growing competition. This signals that the market mechanism will be dominated by business organizations or hospitals which are able to provide excellent services or develop quality, innovative products (Hartono, 2010).

From 2012 to 2017 hospitals in Indonesia increased by an average of 5.2\%. There were 2.773 hospitals in total in Indonesia, some state hospitals and some private ones (Health Ministry, 2017). According to Central Bureau of Statistics (2013), there were 150 hospitals in Jakarta in 2013. Furthermore, according to Central Bureau of Statistics (2015), in 2014 the government of Western Jakarta City ran 38 hospitals. Such fierce competition urged hospitals to perform better and more effective management in running their business in order that they can survive and improve in the haealth business.

They had better know that their success in serving people depends on understanding responses of patients, who are their consumers, and that after-sales service will bring consumer satisfaction (Tciptono, 2004). Consumers play an important role in the success of a company, for a company's assets will be worthless without them. The main job of a company is therefore to attract consumers and keep them interested in its products and services (Kotler \& Armstrong, 1996).

One of the ways important for hospitals to take in promoting their products is to do better marketing. Marketing is a human activity related to the fulfillment of human needs and desires through a process of exchange (Kotler \& Keller, 2009). One important aspect of marketing is marketing mix. It is a set of marketing tools including any element of a program which needs to be considered in order to achieve successful implementation of marketing strategies and the determined position. What is most important is for a company to consider how customers perceive the marketing mix (Rambat Lupiyoadi, 2014).

Marketing mix is commonly known as "4 Ps", namely product, price, place, and promotion. But in the medical world, especially in the healt-care industry, the term marketing mix refers to 5 Ps, the original 4 Ps plus people (Aditama, 2004). Some even add two other Ps, i.e. physical evidence and process (Lupiyoadi \& Hamdani, 2006). Called a mix as such, those tools necessarily affect one another in such a way that disorganization of a tool will backfire the the overall marketing strategy (Lupiyoadi, 2014).

The research by Tafdilla (2016) on the effect of patients' perception of marketing mix on decision to have health service in RSUD Majenang found that $47.9 \%$ of former patients decided not to have another health service. In an almost similar way, the research by Dezolla (2012) on people's decision to get medical treatment in the polyclinic Ambun Pagi of RSUP DR. M. Djamil found that $38.11 \%$ of former patiets decided not to get medical treatment. Furthermore, the research by Mutmainnah (2017) obtained disappointing result that $34.8 \%$ of respondents showed that the relation between the perception of marketing mix and decision to make use of outpatient treatment service in RS Permata in Pamulang is not significant.

According to the research by Setiawan, Darmawansyah, \& Hamzah (2013) entitled "The Relation between Marketing Mix and Inpatients' Interest to Come Back for Other Treatment in RSUD Tenriawaru, Bone", it was found that some variables including product, price, promotion, human resources (people), and physical facilities had a significant relation, while such variables as place and process did not so. Other research by Hakim, Nuryadi, \& Sandra (2015), entitled "The Relation between Marketing Mix and Psychological Factors and Patients' Decision to Make Use of Outpatient Treatment 


\section{STRADA Jurnal Ilmiah Kesehatan}

DOI: $10.30994 /$ sjik.v9i1.210

ISSN: 2252-3847 (print); 2614-350X (online)

Vol.9 No.1. May 2020. Page.206-218

Service", found that all the variables had a significant relation except for physical evidence.

RSIJ Pondok Kopi is in the face of stiff competition with the existence of new hospitals with good facilities. The following table makes available information about polyclinic visits in RSIJ Pondok Kopi from 2015 to 2017.

Table 1: Polyclinic Visits in RSIJ Pondok Kopi from 2015 to 2017

\begin{tabular}{lccc}
\hline \multicolumn{1}{c}{ Types of Polyclinics } & $\mathbf{2 0 1 5}$ & $\mathbf{2 0 1 6}$ & $\mathbf{2 0 1 7}$ \\
\hline Clinic for internal organs & 36.997 & 35.246 & 36.100 \\
Children's clinic & 23.677 & 22.789 & 19.117 \\
Surgical clinic & 15.725 & 17.501 & 29.791 \\
Eye clinic & 11.500 & 11.766 & 10.117 \\
Dental and oral clinics & 6.653 & 5.143 & 4.993 \\
Nerve clinic & 11.448 & 10.564 & 8.957 \\
Heart clinic & 6.756 & 9.510 & 10.789 \\
ENT clinic & 8.740 & 8.754 & 8.896 \\
Lung clinic & 8.060 & 8.306 & 8.521 \\
\hline \multicolumn{3}{c}{ Source: Medical Records in RSIJ Pondok Kopi }
\end{tabular}

The result of medical records in RSIJ Pondok Kopi shows a downward trend in patient attendance at some clinics in 2016 and an upward trend in 2017. Hospital administrators cannot be indifferent to such inconsitent trends because a decrease in the clinic visit rate leads to a decrease in hospital income, which in turn sacrifices the quality of operational duties and professional services.

\section{METHODS}

This research is a quantitative study using the cross sectional method, which is descriptive and analytical. It is aimed at knowing direct and indirect relations which are established and analized at the same time. It was conducted in RSIJ Pondok Kopi, particularly in the outpatient-service unit from April to June of 2018. In the data collection process, the researcher distributed questionarries from the fourth week of May to the second week of June.

\section{RESULTS}

Respondents of the research conducted in RSIJ Pondok Kopi in 2018 were classified into some categories, including sex, age, occupation and educational experience. The overall distribution of those categories is shown in the following table.

Tabel 2: Categories of Outpatients in RSIJ Pondok Kopi in 2018

\begin{tabular}{llcc}
\hline & Categories & N & \% \\
\hline \multirow{2}{*}{ Sex } & Male & 41 & 34,2 \\
& Female & 79 & 65,8 \\
\hline \multirow{4}{*}{ Age } & Children & 19 & 15,8 \\
& Teenager & 24 & 20,0 \\
& Adult & 54 & 45,0 \\
& The old & 15 & 12,5 \\
& The Ripe Old & 8 & 6,7 \\
\hline
\end{tabular}


STRADA Jurnal Ilmiah Kesehatan

DOI: $10.30994 /$ sjik.v9i1.210

ISSN: 2252-3847 (print); 2614-350X (online)

Vol.9 No.1. May 2020. Page.206-218

\begin{tabular}{llcc}
\hline & Students & 20 & 16,7 \\
Occupation & Civil Servant & 9 & 7,5 \\
& Private Employee & 33 & 27,5 \\
& Others & 58 & 48,3 \\
\hline \multirow{3}{*}{ Educational } & Pre-School & 12 & 10,0 \\
Background & Elementary School & 21 & 17,5 \\
& Junior-High School & 36 & 30,0 \\
& Senior-High & 51 & 42,5 \\
\hline
\end{tabular}

Table 2 shows that 79 of all outpatients involved as respondents of the research in RSIJ Pondok Kopi in 2018 were female patients $(65.8 \%)$, outnumbering the male patients which in total numbered 41 patients $(34,2 \%)$. In the age category, adult patients (26-45 years of age) were 54 patients $(45,0 \%)$. This age group outnumbered another group considered to be ripe old patients (66 years or more old), numbering 8 patients $(6,7 \%)$. In the occupational category, 9 of all the repondents $(7.5 \%)$ served as civil servants, while the other 58 repondents $(48.3 \%)$ belonged to other groups, including housewives, retirees, and pre-school children. Meanwhile, in the category of educational backgrounds, respondents graduating from higher education (associate's degree, bachelor's degree, master's degree, and doctoral degree) comprised the largest percentage of the respondents, that is, $42.5 \%$ (51 patients). The rest were 12 pre-school patients $(10,0 \%)$.

\section{Univariate Analysis}

Univariat analyses are done to each of the reseach variables. The distribution of the result of the univariate analysis can be accurately reported as follows.

Table 3: The Distribution of the Frequency of the Decision-Making Process for Having Oupatient Treatment Service in RSIJ Pondok Kopi in 2018

\begin{tabular}{lcccccc}
\multirow{2}{*}{\begin{tabular}{c}
\multirow{2}{*}{ Decision-Making Processes } \\
\cline { 2 - 7 }
\end{tabular}} & \multicolumn{2}{c}{ Agree } & \multicolumn{2}{c}{ Disagree } & \multicolumn{2}{c}{ Total } \\
\cline { 2 - 7 } & $\mathbf{n}$ & $\mathbf{\%}$ & $\mathbf{N}$ & $\mathbf{\%}$ & $\mathbf{n}$ & $\mathbf{\%}$ \\
\hline Identifying a need & 26 & 21,7 & 94 & 78,3 & 120 & 100 \\
Information gathering & 37 & 30,8 & 83 & 69,2 & 120 & 100 \\
Evaluation of alternatives & 44 & 36,7 & 76 & 63,3 & 120 & 100 \\
Purchase Decision & 15 & 12,5 & 105 & 87,5 & 120 & 100 \\
Post-purchase behavior & 23 & 19,2 & 97 & 80,8 & 120 & 100 \\
\hline
\end{tabular}

Table 3 provides indicators for people's decision-making process for having outpatient treatment service in RSIJ Pondok Kopi in 2018. It is known from the table that respondents choose to have outpatient treatment in RSIJ Pondok Kopi for different reasons closely related to steps of decision-making processes: 94 respondents $(78.9 \%)$ made the decision in the step of indentifying a need; 83 respondents $(69.2 \%)$ made it in the step of information gathering; 76 respondents $(63.3 \%)$ did so in the step of evaluation of alternatives; 105 repondents $(87.5 \%)$ did so in the step of purchase decision; and 97 respondents $(80.8 \%)$ did so in the step of post-purchase behavior. 


\section{STRADA Jurnal Ilmiah Kesehatan}

DOI: $10.30994 /$ sjik.v9i1.210

ISSN: 2252-3847 (print); 2614-350X (online)

Vol.9 No.1. May 2020. Page.206-218

Table 4: The Distribution of Frequency of Decision on Having Oupatient Treatment Service in RSIJ Pondok Kopi in 2018

\begin{tabular}{lcc}
\hline \multicolumn{1}{c}{ Decision on Choosing } & $\mathbf{N}$ & $\mathbf{( \% )}$ \\
\hline Agree & 55 & 45,8 \\
Disagree & 65 & 54,2 \\
\hline Total & $\mathbf{1 2 0}$ & $\mathbf{1 0 0}$ \\
\hline
\end{tabular}

Based on table 4, it is known that $65(54.2 \%)$ of the total 120 respondents decided to have outpatient treatment in RSIJ Pondok Kopi in 2018, while the other 55 respondents (55.8\%) decided not to do so.

Table 5: The Distribution of Frequency of Respondents based on the Perception of Marketing Mix of Outpatient Treatment in RSIJ Pondok Kopi in 2018

\begin{tabular}{llcc}
\hline \multicolumn{2}{c}{ Perception of Marketing Mix } & n & \% \\
\hline Product & Poor & 44 & 36,7 \\
& Good & 76 & 63,3 \\
\hline Price & Unreasonable & 18 & 15,0 \\
& Reasonable & 102 & 85,0 \\
\hline Place & Poor & 37 & 30,8 \\
& Good & 83 & 69,2 \\
\hline Promotion & Poor & 40 & 33,3 \\
& good & 80 & 66,7 \\
\hline People/ & Amateur & 44 & 36,7 \\
Human & Professional & 76 & 63,3 \\
Resources & & & \\
\hline Physical & Inadequate & 17 & 14,2 \\
Evidence & Adequate & 103 & 85,8 \\
\hline Process & Complicated & 38 & 31,7 \\
& Simple & 82 & 68,3 \\
\hline
\end{tabular}

Table 5 shows the responses and perception of patients, as the research repsondents, to 7 Ps RSIJ Pondok Kopi offered to them in 2018. From the table, the researcher obtained some information: 76 respondents $(63.3 \%)$ considered products developed to be good products; 102 respondents $(85.0 \%)$ said that RSIJ Pondok Kopi set a reasonable price; 83 respondents $(69.2 \%)$ assessed that RSIJ Pondok Kopi is located in a good place; 80 repondents $(66,7 \%)$ said that RSIJ Pondok Kopi did a good promotion; 76 respondents $(63,3 \%)$ assumed human resources of RSIJ Pondok Kopi to be professional; 103 respondents $(85.8 \%)$ stated that RSIJ Pondok Kopi had adequate physical evidences; and 82 respondents $(68.3 \%)$ said that RSIJ Pondok Kopi applied a straightforward process. 


\section{Bivariate Analysis}

Tabel 7: The Relation betweem the Perception of Marketing Mix and Decision to Have Outpatient Treatmen in RSIJ Pondok Kopi

\begin{tabular}{|c|c|c|c|c|c|c|c|c|c|}
\hline \multicolumn{10}{|c|}{ Decision to Have Outpatient Treatment } \\
\hline \multirow{2}{*}{\multicolumn{2}{|c|}{$\begin{array}{l}\text { Perception of } \\
\text { Marketing Mix }\end{array}$}} & \multicolumn{2}{|c|}{ Disagree } & \multicolumn{2}{|c|}{ afgree } & \multicolumn{2}{|c|}{ Total } & \multirow{2}{*}{$\begin{array}{c}P \\
\text { Valu } \\
e\end{array}$} & \multirow{2}{*}{$\begin{array}{l}\text { OR }(95 \% \\
\text { CI })\end{array}$} \\
\hline & & $\mathbf{N}$ & $\%$ & $\mathbf{N}$ & $\%$ & $\mathbf{n}$ & $\%$ & & \\
\hline \multirow{2}{*}{ Product } & Poor & 32 & 72,7 & 12 & 27,3 & 44 & 10 & \multirow{2}{*}{0,000} & \multirow{2}{*}{$\begin{array}{c}6,145 \\
(2,694- \\
14,014)\end{array}$} \\
\hline & Good & 23 & 30,3 & 53 & 69,7 & 76 & $\begin{array}{c}10 \\
0\end{array}$ & & \\
\hline \multirow{2}{*}{ Price } & $\begin{array}{l}\text { Unreasonab } \\
\text { le }\end{array}$ & 14 & 77,8 & 4 & 22,2 & 18 & $\begin{array}{c}10 \\
0\end{array}$ & \multirow{2}{*}{0,007} & \multirow{2}{*}{$\begin{array}{c}5,207 \\
(1,601- \\
16,940)\end{array}$} \\
\hline & Reasonable & 41 & 40,2 & 61 & 59,8 & $\begin{array}{c}10 \\
2\end{array}$ & $\begin{array}{c}10 \\
0\end{array}$ & & \\
\hline \multirow[b]{2}{*}{ Place } & Bad & 25 & 67,6 & 12 & 32,4 & 37 & 10 & \multirow[b]{2}{*}{0,003} & \multirow{2}{*}{$\begin{array}{c}3,681 \\
(1,619- \\
8,366)\end{array}$} \\
\hline & Good & 30 & 36,1 & 53 & 63,9 & 83 & $\begin{array}{c}10 \\
0\end{array}$ & & \\
\hline \multirow{2}{*}{ Promosi } & Bad & 31 & 77,5 & 9 & 22,5 & 40 & $\begin{array}{c}10 \\
0\end{array}$ & \multirow{2}{*}{0,005} & \multirow{2}{*}{$\begin{array}{c}8,037 \\
(3,324- \\
19,432)\end{array}$} \\
\hline & Good & 24 & 30,0 & 56 & 70,0 & 80 & $\begin{array}{c}10 \\
0\end{array}$ & & \\
\hline \multirow{2}{*}{$\begin{array}{l}\text { People / } \\
\text { Human } \\
\text { resource }\end{array}$} & Amateur & 29 & 65,9 & 15 & 34,1 & 44 & 10 & \multirow[b]{2}{*}{0,002} & \multirow{2}{*}{$\begin{array}{c}3,718 \\
(1,699- \\
8,135)\end{array}$} \\
\hline & Professional & 26 & 34,2 & 50 & 65,8 & 76 & $\begin{array}{c}0 \\
10 \\
0\end{array}$ & & \\
\hline \multirow{2}{*}{$\begin{array}{l}\text { Physical } \\
\text { evidence }\end{array}$} & Inadequate & 12 & 70,6 & 5 & 29,4 & 17 & $\begin{array}{c}10 \\
0\end{array}$ & \multirow{2}{*}{0,051} & \\
\hline & Adequate & 43 & 41,7 & 60 & 58,3 & $\begin{array}{c}10 \\
3\end{array}$ & $\begin{array}{c}10 \\
0\end{array}$ & & \\
\hline \multirow{2}{*}{ Process } & $\begin{array}{l}\text { Complicate } \\
\text { d }\end{array}$ & 23 & 60,5 & 15 & 39,5 & 38 & $\begin{array}{c}10 \\
0\end{array}$ & \multirow{2}{*}{0,045} & \multirow{2}{*}{$\begin{array}{c}2,396 \\
(1,090- \\
5,265)\end{array}$} \\
\hline & Simple & 32 & 39,0 & 50 & 61,0 & 82 & $\begin{array}{c}10 \\
0\end{array}$ & & \\
\hline
\end{tabular}

The Relation between the Perception of Products and the Decision to Have Outpatient Treatment in RSIJ Pondok Kopi

From a statistical calculation using a chi square test, it can be concluded that $p$ value is 0,000 , so that it can be assumed that there is a significant relation between a perception of a product and a decision to have outpatient treatment in RSIJ Pondok Kopi in 2018. An analysis of the result indicated that the OR value is 6,145 , meaning that the number of respondents considering the products to be of poor quality tends to be 6,15 times more than those considering them to be of good quality. 
The Relation between the Perception of Prices and the Decision to Have Outpatient Treatment in RSIJ Pondok Kopi

A statistical test shows that the $p$ value is 0,007 , so it can be concluded that there is a significat relation between a perception of price and a decision to have outpatient treatment in RSIJ Pondok Kopi in 2018. An analysis of the result indicated that the OR value is 5,207, The calculation also indicated that the OR value is 6,145 , meaning that the number of respondents considering the price is unreasonable tends to be 5,20 times more than those considering it to be reasonable.

The Relation between the Perception of Places and the Decision to Have Outpatient Treatment in RSIJ Pondok Kopi

Showing that $\mathrm{p}$ value is 0,003 , a statistical test revealed that there is a significant relation between a perception of place and a decision to have outpatient treatment in RSIJ Pondok Kopi in 2018. An analysis of the result indicated that the OR value is 3,681 , meaning that that the number of respondents considering the place to be of poor quality tends to be 3,68 times more than those considering it to be of good quality.

The Relation between the Perception of Promotion and the Decision to Have Outpatient Treatment in RSIJ Pondok Kopi

A statistical test shows that the $\mathrm{p}$ value is 0,000 , so it can be concluded that there is a significat relation between a perception of promotion and a decision to have outpatient treatment in RSIJ Pondok Kopi in 2018. An analysis of the result indicated that the OR value is 8,037 , meaning that the number of respondents considering the promotion to be a bad promotion tends to be 8,04 times more than those considering it to be a good one.

The Relation between the Perception of People/ Human Resources and the Decision to Have Outpatient Treatment in RSIJ Pondok Kopi

A statistical test shows that the $p$ value is 0,002 , so it can be concluded that there is a significat relation between a perception of people/human resources and a decision to have outpatient treatment in RSIJ Pondok Kopi in 2018. An analysis of the result indicated that the OR value is 3,718 , meaning that the number of respondents considering the human resources to be amateur tends to be 3,72 times more than those considering them to be professional.

The Relation between the Perception of the Physical Evidence and the Decision to Have Outpatient Treatment in RSIJ Pondok Kopi

A statistical test shows that the $\mathrm{p}$ value is 0,051 , so it can be concluded that there is no significant relation between physical evidences and a decision to have outpatient treatment in RSIJ Pondok Kopi in 2018.

The Relation between the Perception of the Process and the Decision to Have Outpatient Treatment in RSIJ Pondok Kopi

A statistical test shows that the $\mathrm{p}$ value is 0,045 , so it can be concluded that there is a significat relation between a perception of process and a decision to have outpatient treatment in RSIJ Pondok Kopi in 2018. An analysis of the result indicated that the OR value is 2,396 , meaning that the number of respondents considering the process to be a complex process tends to be 2,40 times more than those considering them to be a simple one. 


\section{DISCUSSION}

\section{The Relation between the Perception of Products and the Decision to Have Outpatient Treatment in RSIJ Pondok Kopi}

Based on the result of a chi-square test, it was found that the $\mathrm{p}$ value is 0,000 ( $p$ value $>0,05$ ), so that a perception of products was significantly related to a decision to have outpatient treatments in RSIJ Pondok Kopi. This result corroborates the research by Tafdilla (2016) finding that the $\mathrm{p}$ value is 0,000 which means there is a significant relation between marketing mix of products and patients' decision to have health service in RSUD Majenang. It is also in line with the research by Toding, Palutturi, \& Nurhayani (2014) with the $p$ value $=0,007$ which found that there is a significant relation between marketing mix of products and patients' interest to have outpatient treatments in RSIA Elim Makassar.

Respondents assessed that in terms of marketing mix of products RSIJ Pondok Kopi has an adequate number of doctors, clinics which patients can visit every day, and other facilities meeting patients' needs and desires. This supports the theory of Kotler (1997) stating that products form the most important basic element in marketing mix in the form of everything which can be put on market to fulfill needs and desires. According to the theory of Supriyanto \& Ernawaty (2010), such fulfillness of patients' needs and desires can accelerate the rate of the use of services and even loyal consumers, who are in this term patients.

\section{The Relation between the Perception of Prices and the Decision to Have Outpatient Treatment in RSIJ Pondok Kopi}

Based on the result of a chi-square test, it was found that the $\mathrm{p}$ value is 0,007 ( $p$ value $>0,05$ ), so that a perception of prices was significantly related to a decision to have outpatient treatments in RSIJ Pondok Kopi. This is in line with another research by Setiawan et al (2013) with $p$ value $=0,021$ which showed the significant relation of marketing mix of prices with outpatients' interest to come back and have another health service in RSUD Tentriawaru Bone. Similarly, the research by Sembor, Ratty, \& Kaunang (2015) found that the $\mathrm{p}$ value is 0,000 , came up with a similar result that there is a significant relation between marketing mix and patients' loyalty in the outpatient treatment unit of RS Siloam Manado with the $\mathrm{p}$ value $=0,000$.

Aditama (2004) said that prices serve to shape comsumer perception of promoted products more than to merely recover production costs and make profits. According to Winardi(1989), prices for buyres are values set to appreciate what they get in exchange. Therefore, whether or not a product is affordable very much depends on one's income. This is supported by the fact that most patients considered the cost to health services or medical check up to be affordable and reasonable. This indicates that their coming back for another health service is quite possible.

\section{The Relation between the Perception of Places and the Decision to Have Outpatient Treatment in RSIJ Pondok Kopi}

Based on the result of a chi-square test, it was found that the $\mathrm{p}$ value is 0,003 ( $p$ value $>0,05$ ), so that a perception of places was significantly related to a decision to have outpatient treatments in RSIJ Pondok Kopi. This is in line with the research by Yuningsih (2009) find that the $p$ value is 0,007 , which means that marketing mix of places bears a close relation with peoples' decision to have outpatient treatment in RS Haji of Jakarta. Another research with the similar result is the one conducted by Wijayanti, Amir, \& Indar (2013), which showed a significant relation of marketing mix of places with loyalty of patients in RSUD of Makassar City, with the $p$ value $=0,002$. 
According to Lupiyoadi \& Hamdani (2006), selecting places or locations needs such careful considerations as accessibility, visibility, traffic routes, parking space, expansion, hospitable environments, and competition. Patients' decision to have health care in RSIJ Pondok Kopi brings them a real experience of taking such considerations. Mcleod (2005), as cited in Widjaja (2009), said that a strategic location gives a company great advantages of easy access for consumers, despite its higher costs of rent payment and investment funds. In contrast, places not strategically located boost larger marketing budget to attract customers' interest to visit. Poernomo (2009) stated that marketing mix of places in general is an effort to showcase promoted products at the right time and in the right place in accordance with consumers' needs.

\section{The Relation between the Perception of Promotion and the Decision to Have Outpatient Treatment in RSIJ Pondok Kopi}

Based on the result of a chi-square test, it was found that the $\mathrm{p}$ value is 0,000 ( $p$ value $>0,05$ ), so that a perception of promotion was significantly related to a decision to have outpatient treatments in RSIJ Pondok Kopi. Correspondingly, the research by Purnamasari, Nurhayani, Hamzah, \& Amir(2011) found that the p value is 0,000 , which shows a significant relation of marketing mix of promotion with patients' visit in the unit of outpatient treatment of RSIA Pertiwi of Makassar. This also corroborates the research by Khatimah, Hamzah, \& Nurhayati (2014) finding that marketing mix of promotion is related to the quality of patient care in the unit of outpatient treatment of RS Ibnu Sina of Makassar.

Marketing mix of promotion uses five primary tools: advertisements, sales promotionpublic relations, personal selling, and direct selling (Kotler, 2004). One of the promotional strategies RSIJ Pondok Kopi adopted was to establish a public relation by sharing information in a particular event or to foster a collaboration. It is known in this research that the number of people deciding to have a health service in the hospital is more than that of people deciding not to do so. This means that the information shared by the hospital has succeeded in attracting public attention to get medical treatment.

In marketing, promotion is to communicate ideas, messages and information, in this term communication established by hospitals with their potential consumers (Aditama, 2004). The success of a promotion usually breeds the success of the overall marketing campaign, which is indicated by a high volume of sales, sales growth, increasing number of customers, and market share (Ferdinand, 2002).

\section{The Relation between the Perception of People/ Human Resources and the Decision to Have Outpatient Treatment in RSIJ Pondok Kopi}

Based on the result of a chi-square test, it was found that the $p$ value is 0,002 ( $p$ value $>0,05$ ), so that a perception of people/human resources was significantly related to a decision to have outpatient treatments in RSIJ Pondok Kopi. This is comparable to at least two other studies: (1) the research by Nurlia, Hamzah, \& Indar (2012) which foud that the $\mathrm{p}$ value is 0,002 , which means that marketing mix of people/ human resources has a significant relation with patients' decision to have health service in RSI of Makassar, and (2) the research by Alfianti, Karimuna, \& Rasma (2016) finding that the p value is 0,005 , meaning there is a significant relation between marketing mix of people and decision of outpatients in RSU Bahterama of Southeast Sulawesi.

In service industry, people or human resources serve as service providers upon whom the quality of services highly depend (Lupiyoadi \& Hamdani, 2006). On consideration, all healthcare workers must be equipped with skills and training to realize what is most important in their job, that is, to satisfy costumers' needs. This must be taken into 
consideration of a hospital so as to maintain top service quality, despite inevitably arising costumer complaints about the performance of human resources.

\section{The Relation between the Perception of the Physical Evidence and the Decision to Have Outpatient Treatment in RSIJ Pondok Kopi}

Based on the result of a chi-square test, it was found that the $p$ value is 0,051 ( $p$ value $>0,05$ ), so that a perception of physical evidence had no significant relation with a decision to have outpatient treatments in RSIJ Pondok Kopi. This is just in line with the research by Alfianti et al., (2016) which found that the p value is 0,959 , which means there was no significant relation between physical evidence with outpatients' decision to have health service in RSUD Bahteramas. The research by Toding et al.(2014) finding the $p$ value is 0,540 showed no significant relation between marketing mix of physiscal evidence and outpatients' interest to come back to RSIA Elim of Makassar for another health care. However, this research is contrary to the research by Hardiyanti (2012) showing a significant relation between physical evidence and outpatients' visit at RSIA Pertiwi.

Respondents complaining about poor quality of physical evidence tend to outnumber those considering it to be good one. In fact, the physical evidence of RSIJ Pondok Kopi was deemed to be sufficient probably because of its complete sign boards and generous bill payment to the extent that patients felt satisfied with the physical evidence given to them. According to Tciptono (2007), in his book "Pemasaran Jasa", explained that many service providers differentiate their services from those of their competitors by adding physical features such as room designs, crew uniforms, and exclusive service outlets. Physical comfort including good and clean buildings, comfortable waiting rooms, attractive designs, and complete sign boards can also improve the quality of services.

\section{The Relation between the Perception of the Process and the Decision to Have Outpatient Treatment in RSIJ Pondok Kopi}

Based on the result of a chi-square test, it was found that the $p$ value is 0,045 ( $p$ value $>0,05$ ), so that a perception of process had no significant relation with a decision to have outpatient treatments in RSIJ Pondok Kopi. This is in line with the research by Purnamasari et al. (2011) which found that the $p$ value is 0,000 , which means that there is a close relation between marketing mix of process and patients' visit at the unit of outpatient treatment of RSIA Pertiwi of Makassar. In similar way, with $p$ value $=0,001$, the reseacrh by Rita (2015) showed a significant relation of marketing mix of process with loyalty of patients.

The result of the research reflects real experience patients got while having health service in RSIJ Pondok Kopi. In answering questionnaire questions, they said that they did not have to wait for a long time to make payment or wait for drug prescription, that doctors do medical check ups on time, and that administrative procedures were not complicated. According to the theory of Tciptono(2007), in addition to final results, production processes form contributory factors to the quality of services. For this reason, hospitals or other service providers must take into consideration processes and the way their crew interact with customers.

\section{CONCLUSION}

Characteristics of respondents of this research were distributed to some categories, including sex, age, occupation, and educational background. In the sex category, most of the respondents were women which numbered 79 respondents $(65,8 \%)$. In the catefory of age group, adult respondents, who were 26 to 45 years old, formed the largest group of respondents, with the total number of 54 respondents $(45,0 \%)$. In the occupation category, 
most repondents belong to the non-public servant group, with the total number of 58 respondents $(48.3 \%)$. They were housewives, the retirees, or pre-school children. Meanwhile, in the category of educational backgrounds, most of the respondents were university graduates, with the total number of 51 respondents $(42,5 \%)$.

The result of the analysis of people's decision to have or not to have a health service shows that the majority of respondents, 65 respondents $(54.2 \%)$, decided to have a health srvice, while those deciding not to do so numbered 55 respondents $(45,8 \%)$.

The result of the analysis of people's decision-making process, the majority of respondents, 83 respondents $(69.2 \%)$, decided to have a health service in the step of a problem or need identification, another 76 respondents $(63.3 \%)$ did so in the step of evaluating alternatives, another 105 respondents $(87,5 \%)$ did so in the step of purchase decision, and the other 97 respondents $(80,8 \%)$ did so in the step of post-putchase behavior.

The research analysis shows that the majority of respondents had positive perceptions of all the variables of marketing mix done by RSIJ Pondok Kopi: 76 respondents $(63.3 \%)$ perceived the products to be good products; 102 repondents $(85.0 \%)$ perceived the price to be reasonable; 83 respondents $(69.2 \%)$ perceived RSIJ to be located in a good place; 80 respondents $(66.7 \%)$ perceived RSIJ to do good promotion; 76 respondents $(63.3 \%)$ perceived RSIJ to have profesional human resources (people); 103 respondents $(85.8 \%)$ perceived the physical evidence to be adequate ; and 82 respondents $(31.7 \%)$ perceived RSIJ to facilitate a process of simple procedures.

Six of all the variables, including products, prices, places, promotions, people or human resources, and processes, were found to have significant relations with people's decision to have outpatient treatment service in RSIJ Pondok Kopi in 2018. The variable of physical evidences became the only not to have a significant relation with the decision..

\section{SUGGESTION}

It is advisable that RSIJ Pondok Kopi improve the quality of its services by providing its healthcare workers with extensive training in service of excellence and add bench seats on which patients can sit wait for drug prescriptions.

It is important for future studies and research on marketing mix to utilize a method combining quantitative and qualitive methods for more accurate and more reliable information.

\section{REFERENCES}

Aditama, T. Y. (2004). Manajemen Administrasi Rumah Sakit (Edisi 2). Jakarta: UI-Press.

Alfianti, K. R., Karimuna, S., \& Rasma. (2016). Hubungan Bauran Pemasaran (Marketing Mix) dengan Keputusan Pasien Rawat Inap Memilih Layanan Kesehatan di Rumah Sakit Umum Bahteramas Provinsi Sulawesi Tengah Tahun 2016. Jurnal Mahasiswa Kesehatan Masyarakat, Universitas Halu Oleo, 2(5), 250-731.

Badan Pusat Statistik. (2013). Jumlah Rumah Sakit Umum, Rumah Sakit Khusus dan Puskesmas Menurut Provinsi 2012 dan 2013. Diambil 14 Juli 2018, dari https://www.bps.go.id/linkTableDinamis/view/id/933

Badan Pusat Statistik Kota Jakarta Timur. (2015). Jumlah Sarana Kesehatan Menurut Kecamatan Tahun 2014. Diambil 10 April 2018, dari https://jaktimkota.bps.go.id/dynamictable/2015/12/29/7/jumlah-fasilitas-kesehatanmenurut-kecamatan-2014.html

Dezolla, D. (2012). Hubungan Bauran Pemasaran dengan Keputusan Memilih Berobat di 
Poliklinik Ambun Pagi RSUP DR. M. Djamil Padang Tahun 2012. Universitas Jember.

Hakim, F., Nuryadi, \& Sandra, C. (2015). Hubungan Bauran Pemasaran dan Faktor Psikologis dengan Proses Pengambilan Keputusan Pasien dalam pemanfaatan Rawat Jalan. Jurnal Pustaka Kesehatan, 3(3). Diambil dari http://download.portalgaruda.org/article.php?article=478571

Kementerian Kesehatan. (2017). Sistem Informasi Rumah Sakit, Pelayanan Kesehatan. Diambil 22 Juli 2018, dari http://sirs.yankes.kemkes.go.id/rsonline/report/

Khatimah, H., Hamzah, A., \& Nurhayati. (2014). Pengaruh Bauran Pemasaran terhadap Mutu Pelayanan Pasien di Instalasi Rawat Inap Rumah Sakit Ibnu Sina Makassar. Universitas Hasanuddin.

Kotler, P., \& Armstrong, G. (1996). Dasar-Dasar Pemasaran Jilid 1. Jakarta: Prehalindo.

Kotler, P., \& Keller, K. (2009). Manajemen Pemasaran (Edisi 13,). Jakarta: Erlangga.

Lupiyoadi, R. (2014). Manajemen Pemasaran Jasa (Edisi 3). Jakarta: Salemba Empat.

Lupiyoadi, R., \& Hamdani, A. (2006). Manajemen Pemasaran Jasa (Edisi 2). Jakarta: Salemba Empat.

Mutmainah, S. (2017). Hubungan Persepsi tentang Bauran Pemasaran dengan Proses Pengambilan dalam Pemanfaatan Rawat Inap di Rumah Sakit Pamulang Tahun 2017. Universitas Muhammadiyah Jakarta.

Nurlia, C., Hamzah, A., \& Indar. (2012). Hubungan Bauran Pemasaran dengan Keputusan Pasien Rawat Inap Memilih Layanan Kesehatan di Rumah Sakit Islam Faisal Makassar Tahun 2011. Universitas Hasanuddin.

Poernomo, D. I. S. (2009). Analisis Pengaruh Persepsi Pasien Tentang Bauran Pemasaran Terhadap Loyalitas Pasien Di Poliklinik Rawat jalan RS Baptis Kediri. Universitas Dipenogoro.

Purnamasari, A., Nurhayani, Hamzah, A., \& Amir, Y. (2011). Hubungan Bauran Pemasaran (Marketing Mix) dengan Kunjungan Pasien di Unit Rawat Jalan RSIA Pertiwi Makassar Tahun 2011. Jurnal Administrasi Kebijakan Kesehatan, 1(1), 1115.

Rita, N. (2015). Hubungan Bauran Pemasaran Jasa Pelayanan Keperawatan dengan Loyalitas Pasien. Universitas Andalas, Padang.

Sembor, P. E., Ratty, A. J., \& Kaunang, W. P. (2015). Hubungan Antara Persepsi Pasien Tentang Bauran Pemasaran Jasa Dengan Loyalitas Pasien Di Unit Rawat Jalan Rumah Sakit Siloam Manado, 1(1). Diambil dari https://ejournalhealth.com/index.php/t2/article/view/134

Setiawan, A., Darmawansyah, \& Hamzah, A. (2013). Hubungan Bauran Pemasaran dengan Minat Kembali Pasien Rawat Inap RSUD Tenriawaru Bone. Universitas Hasanuddin.

Supriyanto, S., \& Ernawaty. (2010). Pemasaran Industri Jasa Pelayanan Kesehatan. Yogyakarta: Andi.

Tafdilla, A. (2016). Pengaruh Persepsi Pasien Tentang Bauran Pemasaran Terhadap Keputusan Pasien Rawat Jalan Memilih Layanan Kesehatan Di Rumah Sakit Umum Daerah Majenang Tahun 2015. Universitas Negeri Semarang.

Tciptono, F. (2004). Manajemen Jasa (Edisi 1). Yogyakarta: Andi.

Tciptono, F. (2007). Strategi Pemasaran (Edisi 2). Yogyakarta: Andi. 
Toding, E., Palutturi, S., \& Nurhayani. (2014). Hubungan Bauran Pemasaran dengan Minat Kembali Pasien Rawat RSIA Elim Makassar. Universitas Hasanuddin.

Widjaja, B. (2009). Lifestyle Marketing. Jakarta: Gramedia Pustaka Utama.

Wijayanti, D., Amir, \& Indar. (2013). Hubungan Bauran Pemasaran dengan Loyalitas Pasien di Unit Rawat Jalan RSUD Kota Makassar. Universitas Hasanuddin.

Winardi. (1989). Aspek-aspek Bauran pemasaran (Marketing Mix). Bandung: Mandar Maju.

Yuningsih. (2009). Hubungan Bauran Pemasaran Dengan Keputusan Memilih Berobat di Sub Bagian Rawat Jalan Rumah Sakit Jakarta Tahun 2009. Universitas Indonesia, Depok. 